\title{
PENGEMBANGAN MODEL BUKU PENGAYAAN BERBASIS CERITA RAKYAT LAMPUNG
}

\section{DEVELOPING A MODEL OF ENHANCEMENT BOOK BASED ON LAMPUNG FOKLORE}

\author{
Dian Anggraini
}

Kantor Bahasa Lampung

Ponsel: 082179926870; Pos-el: diansastralampung@gmail.com

\begin{abstract}
Abstrak
Tujuan penelitian ini menghasilkan bahan bacaan berupa "Pengembangan Model Buku Pengayaan Berbasis Cerita Rakyat Lampung". Penelitian ini menggunakan metode penelitian dan pengembangan menurut Borg and Gall dengan mengadaptasi lima langkah penelitian. Instrumen, survei, angket, dan wawancara merupakan teknik pengumpulan data lapangan. Populasi dalam penelitian ini adalah siswa kelas empat SD pada tiga sekolah di Kota Bandarlampung sebanyak 70 siswa dengan teknik random sampling. Hasil penelitian ini berupa buku pengayaan yang dapat digunakan untuk pembelajaran di kelas dan pemerkaya bahan bacaan literasi. Buku pengayaan ini memiliki kekhasan, yaitu berupa buku guru dan buku siswa yang dilengkapi dengan kebutuhan mereka. Tiga orang pakar memberikan penilaian rata-rata 88 persen sehingga dinyatakan sangat layak dipergunakan baik siswa maupun guru.
\end{abstract}

Kata kunci: model; buku pengayaan; pembelajaran; cerita rakyat Lampung

\begin{abstract}
The purpose of this study is to create reading materials in the form of "A Model of Enhancement Book Based on Lampung Folklore". This research method uses research and development of Borg and Gall by adapting five steps of research. The data are collected by using Instruments, surveys, questionnaires, and interviews. The population in this study is 70 students taken by using random technique from fourth grade elementary school students in three schools in Bandar lampung City. The results of the study are enrichment books that can be used for classroom learning and enrich literacy reading materials. The Model of enhancement books has specialties. These specialties meant are the teacher's books and student books are created based on their needs. Three experts gave an average rating of 88 percent, so it is remarkably appropriate to be used both by students and teachers.
\end{abstract}

Keywords: Model; enrichment book; learning; folklore of Lampung 


\section{Pendahuluan}

Kementerian Pendidikan dan Kebudayaan merilis hasil pemetaan kompetensi literasi yang dilakukan oleh Programme for Internasional Student Assesment (PISA) tahun 2016. Hasil pemetaan tersebut menunjukan bahwa tingkat literasi Indonesia berada di urutan ke-64 dari 72 negara yang disurvei (PPSDK, 2018).

Rendahnya tingkat literasi masyarakat Indonesia menjadi salah satu persoalan yang cukup rumit. Berbagai faktor dilansir menjadi penyebab utama, seperti rendahnya motivasi siswa untuk membaca, minimnya dukungan orang tua, dan ketidaktersediaan buku bacaan sesuai minat siswa.

Untuk mengatasi hal tersebut, tentu semua pihak harus bekerja keras. Pemerintah harus melakukan sinergitas dengan berbagai pihak, baik lembaga pemerintahan, swasta, maupun lembaga nonprofit.

Mempersiapkan bahan bacaan yang mengandung muatan lokal merupakan salah satu upaya untuk mengatasi minimnya ketersediaan buku. Hal itu sekaligus menjadi upaya meningkatkan motivasi anak untuk membaca. Jika anak mengenal kebudayaannya sedari kecil, secara tidak langsung karakter mereka akan terbentuk sesuai dengan lingkungan tempat tinggal mereka masing-masing.

Piil pesengiri merupakan prinsip hidup masyarakat Lampung yang diyakini dapat membentuk karakter seorang pemimpin masa depan karena memuat kristalisasi nilai karakter yang dibutuhkan siswa. Karakter tersebut antara lain mandiri, gotong royong, religius, integritas, dan nasionalis.

$$
\text { Rahmanto (1988) menyatakan }
$$

bahwa siswa biasanya akan mudah tertarik pada buku-buku karya sastra dengan latar belakang yang erat hubungannya dengan latar belakang kehidupan mereka. Terlebih lagi jika karya sastra itu menghadirkan tokoh yang berasal dari lingkungan mereka dan mempunyai kesamaan dengan mereka atau masyarakat di dekatnya.

Buku yang tepat adalah buku yang memberikan perhatian pada pertumbuhan psikologi pembacanya. Bila ditujukan bagi pembaca awal (sekolah dasar), penulis telah mengenal kebutuhan bahan bacaan siswa, meliputi jenis bahan bacaan, tema, serta ilustrasi agar buku tersebut menarik hati anak.

Hal-hal yang berkaitan dengan dunia atau kehidupan anak adalah dasar bagi penulis untuk menyediakan bahan- 
bahan bacaan yang baik bagi anak. Semua itu harus diletakkan dalam konteks budaya anak-anak (Sarumpaet, 2009). Dengan demikian, segala tindakan harus memperhatikan objek yang penerima. Jika anak sebagai objek penerima, penulis harus memperhatikan dunia anak.

Budaya lokal (Herpratiwi, 2016) adalah hasil karya cipta dan warisan dari leluhur. Leluhur tidak hanya nenek moyang, tetapi juga para budayawan, akademisi, dan para praktisi di bidangnya masing-masing. Karya cipta tersebut bertujuan membentuk masyarakat yang lebih berkepribadian sesuai karakater bangsa.

Lebih lanjut Sarumpaet (2009) mengatakan bahwa pengetahuan sastra tradisional akan membantu penikmatnya untuk mengenal lingkungan di dekatnya yang cenderung menampakkan keberagaman situasi. Segala situasi, peristiwa, keinginan, dan juga impian dari tokoh-tokoh dalam cerita dapat membantu pembaca untuk mengatasi persoalan-persoalan yang dihadapi pada masa yang akan datang.

Berdasarkan pendapat tersebut, peneliti ini memfokuskan diri pada penelitian pengembangan buku pengayaan berbasis cerita rakyat Lampung. Penelitian ini penting untuk dilakukan karena buku cerita rakyat Lampung saat ini masih sulit ditemukan, baik di perpustakaan milik pemerintah, maupun di perpustakaan-perpustakaan sekolah. Masalah tersebut ditemukan dari hasil pengolahan data prapenelitian di tiga sekolah, yaitu SDN 2 Kupangteba Bandarlampung, SDN 3 Sawahlama Bandarlampung, dan SD IT Khoirul Ummah. Ketiga sekolah tersebut belum memiliki buku cerita rakyat yang berasal dari Provinsi Lampung. Saat berkunjung ke perpustakaan, siswa hanya mendapatkan buku-buku cerita rakyat dari provinsi-provinsi lain. Begitu pula saat siswa sedang belajar di dalam kelas. Cerita rakyat yang terdapat dalam buku pelajaran berasal dari daerah-daerah lain yang memiliki karakter berbeda dengan daerah asal mereka.

Pengembangan buku pengayaan berbasis cerita rakyat Lampung yang mengandung prinsip-prinsip hidup masyarakatnya sangat penting dilakukan. Siswa sekolah dasar membutuhkan bahan bacaan untuk mendukung perkembangan sikap, pengetahuan, manajemen emosi, dan rasa ingin tahu mereka. Jika sedari kecil siswa mengenal bahan bacaan yang memiliki manfaat yang sangat besar dalam kehidupan mereka, ketika besar siswa akan mampu beradaptasi dengan 
lingkung, lebih menghargai orang lain, dan lebih kuat menghadapi rumitnya persoalan yang dihadapi.

Dari latar belakang tersebut, peneliti merumuskan beberapa permasalahan yang akan dibahas, yaitu (1) Bagaimanakah kebutuhan pengajar dan murid terhadap buku pengayaan berbasis cerita rakyat Lampung? (2); Bagaimanakah ciri-ciri buku pengayaan berbasis cerita rakyat Lampung?; dan (3) Bagaimanakah kelayakan buku pengayaan berbasis cerita rakyat Lampung?

\section{Landasan Teori}

Produk penelitian ini mencakup beberapa jenis cerita tradisional, yaitu dongeng, legenda, dan mite. Cerita yang disusun mengandung prinsip hidup rakyat Sai Bumi Ruwa Jurai yang akan memberikan manfaat yang cukup dalam kepada pembacanya, terutama berkaitan dengan pembentukan karakter murid. Hasil analisis prapenelitian ini menjadi alasan utama untuk melakukan terobosan dalam penyediaan bahan bacaan yang sesuai dengan kebutuhan murid dan tenaga pengajar.

Melalui buku ini siswa akan mengetahui budaya yang dimiliki masyarakat tempat tinggalnya. Budaya yang dimaksud seperti bagaimana bertahan hidup, bagaimana cara untuk berperilaku, bagaimana cara untuk mengambil keputusan, dan lain-lain.

Suku Lampung memiliki prinsip hidup yang menjadi pedoman dalam kehidupan bermasyarakat. Hal ini merupakan salah satu identitas diri mereka. Prinsip hidup yang dimaksud adalah piil pesengiri. Prinsip hidup ini menjadi petunjuk bagi masyarakat dalam berinteraksi dengan pendatang atau masyarakat sekitar.

Empat pilar penopang kokoh pedoman ini, yaitu juluk adek, nemui nyimah, nengah nyappur, dan sakai sambayan.

Juluk adek merupakan gelar yang yang diterima masyarakat Lampung ketika mereka telah dewasa dan berumah tangga. Gelar ini diresmikan dalam acara adat di hadapan para pemuka kerabat atau tua-tua adat.

Nemui nyimah merupakan kebiasaan orang Lampung berbuat baik pada orang lain, misalnya membantu orang yang membutuhkan tanpa mengharapkan balas budi. Perilaku ini berlangsung dari kecil hingga dewasa. Nengah nyappur menunjukan bahwa orang Lampung senang bergaul dengan siapa saja tanpa membedakan golongan. 
Sakai sambayan menunjukkan sikap kebersamaan. Tidak hanya bekerja sama dalam bentuk tenaga, tetapi juga dalam persoalan keuangan. Kegiatan ini biasanya berlaku dalam usaha pertanian, pesta perkawinan, adat istiadat, pembangunan rumah bersama atau balai adat, masjid, dan lainnya (Hadikusuma, 1989).

Melalui buku pengayaan ini, diharapkan pembaca (siswa) akan mempunyai karakter yang lebih dinamis. Karakter yang dimaksud, seperti memiliki kepercayaan diri, bertanggung jawab, menghormati pihak lain, mudah beradaptasi, dan dapat menghadapi masalah dalam kehidupan sehari-hari.

Pengembangan buku pengayaan berbasis cerita rakyat Lampung ini dilakukan untuk menghasilkan buku pengayaan yang ditujukan kepada siswa dan guru. Buku siswa akan dilengkapi dengan petunjuk dan lembar aktivitas, sedangkan buku guru akan diperkaya dengan rancangan perencanaan pembelajaran, pemetaan indikator pembelajaran, dan petunjuk bagi guru.

\section{Metode Penelitian}

Metode penelitian yang digunakan dalam penelitian ini adalah penelitian dan pengembangan atau Research \& Development Borg and Gall (Sugiyono, 2013). Borg dan Gall menyatakan ada sepuluh langkah yang harus ditempuh dalam pendekatan ini, yaitu "research and information collecting, planning, develop preliminary form of product, preliminary field testing, main product revision, main field testing, operational product revision, operational field testing, final product revision, and dissemination and implementation". Sepuluh langkah penelitian dan pengembangan Borg $\mathrm{n}$ Gaal terlihat dalam gambar berikut. 


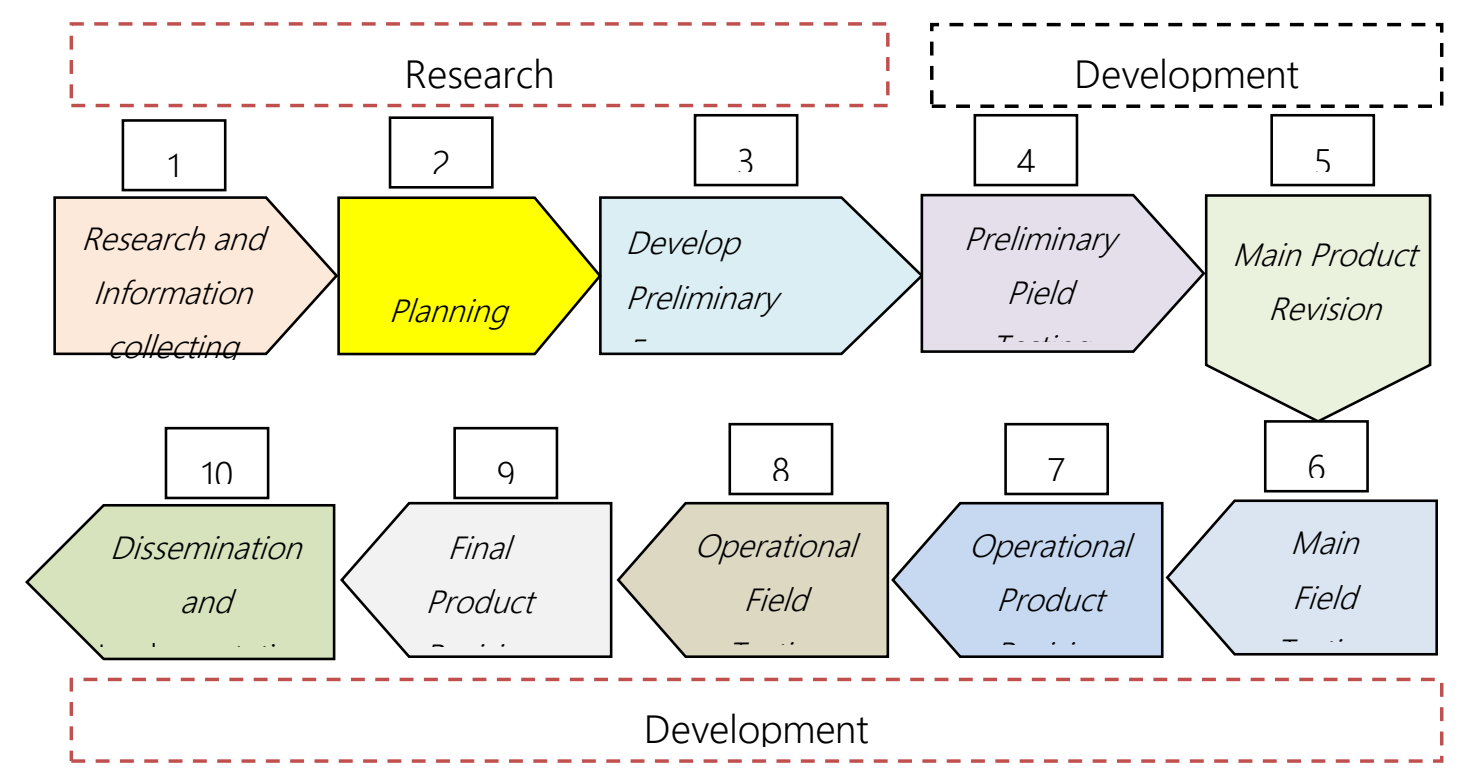

Gambar 1. Sepuluh Research \& development menurut Borg \& Gall

Untuk mengembangan produk buku pengayaan berbasis cerita rakyat Lampung, peneliti hanya melakukan lima tahapan. Hal ini disebabkan keterbatasan waktu. Walaupun hanya melalui lima tahapan, penelitian ini telah melalui tahapan penilaian tiga orang pakar.

Data kebutuhan berasal dari tiga sekolah dasar di Kota Bandarlampung, yaitu SDN 2 Kupangteba, SDN 3 Sawahlama, dan SD IT Khoirul Ummah. Populasi penelitian ini adalah siswa kelas 4 SD yang menjadi sampel penelitian dengan menggunakan teknik random sampling.

Penelitian ini membutuhkan tiga data berbeda, yaitu data kebutuhan produk buku pengayaan dan pengetahuan; pelaksanaan GLS dan PPK; dan penilaian pakar dalam bentuk skor kecenderungan pilihan jawaban. Data tersebut kemudian diubah menjadi data kualitiatif untuk mendeskriptif hasil analisis.

Data bersumber dari murid, tenaga pengajar, dan pakar. Data dari siswa berupa kebutuhan buku pengayaan, data dari guru berupa kebutuhan buku pengayaan serta pengetahuan dan pelaksanaan GLS, dan data dari pakar berupa penilaian terhadap produk.

Alat bantu yang digunakan untuk mengumpulkan data berupa panduan survei, kuesioner, dan wawancara. Panduan survei digunakan untuk melakukan pemantuan terhadap ketersediaan buku, sedangkan panduan kuesioner untuk mengetahui kebutuhan siswa dan guru serta penilaian para pakar 
terhadap produk. Pandungan wawancara berfungsi untuk mendapatkan tanggapan secara lisan dari siswa dan guru terkait.

Analisis data menggunakan analisis deskriptif dengan berpegang pada penilaian dari tiga orang pakar pada kuesioner yang disediakan.

Rata-rata poin dari skala likert pada aspek dan domain masing-masing merupakan aktivitas analisis data. Pemberian skor dari kuesioner dikategorikan sebagai berikut ini.

- Sangat layak bernilai 1;

- Kurang layak bernilai 2;

- Cukup bernilai 3;

- Layak bernilai 4; dan

- Sangat layak bernilai 5.

Skor tersebut akan menghasilkan persentase dengan menggunakan rumus berikut.

Persentase $=$ Jumlah Skor $\times 100 \%$ Skor maksimal

Hasil pengolahan skor dalam bentuk persentase akan memperlihatkan kelayakan dari produk yang dihasilkan, yaitu buku siswa dan buku guru. Selanjutnya, kelayakan tersebut akan diolah ke dalam data kuantitatif dengan menggunakan persepsi skor (Riduwan \& Sunarto, 2009).

\section{Pembahasan}

Produk penelitian ini berupa model buku pengayaan berbasis cerita rakyat Lampung yang dilengkapi dengan falsafah hidup masyarakatnya.

Analisis kebutuhan siswa dan guru merupakan langkah awal penelitian ini. Hal ini disebabkan siswa membutuhkan buku pengayaan yang memuat cerita rakyat Lampung. Model buku pengayaan tersebut memuat kearifan lokal masyarakat Lampung. Selama ini siswa tidak pernah membaca cerita rakyat Lampung sehingga mereka tidak mengenal budaya Lampung. Mereka hanya membaca cerita rakyat dari provinsi lain, seperti Sumatera Barat, Sumatera Utara, Jawa Barat, Jawa Timur, dan Kalimantan.

Selain itu, siswa juga menginginkan buku yang memiliki desain menarik. Buku tersebut menggunakan warna cerah dengan ilustrasi yang mendukung cerita. Siswa juga menginginkan buku dengan tingkat keterbacaan yang tinggi sehingga mudah dipahami. Jika menggunakan istilah daerah, siswa menginginkan istilah tersebut dipadankan pula ke dalam bahasa Indonesia.

Guru sebagai ujung tombak pembelajaran di kelas membutuhkan 
buku cerita rakyat Lampung untuk mengajar kompetensi dasar (KD) 3.9 (Mencermati tokoh-tokoh yang terdapat pada teks fiksi) dan KD 4.9 (Menyampaikan hasil identifikasi tokohtokoh yang terdapat pada teks fiksi secara lisan, tulis, dan visual guru). Selama ini, guru terpaksa menggunakan cerita rakyat dari provinsi- provinsi lain, seperti Jawa Barat, Sumatera Utara, Sulawesi Selatan, dan Kalimantan. Cerita-cerita rakyat dari provinsi-provinsi tersebut terdapat dalam buku teks pelajaran, baik yang diterbitkan oleh Kementerian Pendidikan dan Kebudayaan, maupun dari penerbit swasta. Guru juga belum memiliki buku pengayaan untuk mendukung KD tersebut.

Selain itu, guru menginginkan cerita rakyat mampu mengenalkan budaya Lampung kepada siswa. Dengan mengenal kearifan lokal sedari kecil, karakter murid akan terbentuk. Siswa juga akan menyesuaikan diri dengan budaya yang diketahui dan dipercaya sebagai pedoman hidup. Ke depan, siswasiswa tersebut akan lebih mudah berinterakasi dengan lingkungan sosialnya. Guru juga menghendaki buku pengayaan memiliki desain menarik agar mampu meningkatkan minat baca siswa dan memiliki tingkat keterbacaan yang tinggi.

Adapun langkah-langkah proses pengembangan buku pengayaan mengikuti langkah-langkah yg disarankan Sugiyono (2013), yaitu survei pendahuluan, pengembangan prototipe, desain produk, validasi desain, perbaikan desain, dan produk akhir buku pengayaan.

\subsection{Survei Pendahuluan}

Survei pendahuluan terdiri atas dua aktivitas. Aktivitas pertama adalah mencari referensi-referensi, seperti hasilhasil penelitian sebelumnya yang memiliki korelasi dengan penelitian yang akan dilakukan. Dalam hal ini, peneliti mendatangi berbagai tempat untuk mendapatkan informasi-informasi yang diperlukan, seperti perpustakaan milik pemerintah dan swasta.

Beberapa penelitian sebelumnya yang memiliki keterkaitan dengan penelitian ini di antaranya penelitian yang dilakukan Mehta (2013), Nugroho (2013), dan Puspita (2015). Penelitian yang telah dilakukan tersebut tidak sama dengan penelitian ini. Hasil penelitian Mehta (2013) mendeskrifsikan cerita-cerita tradisional yang memiliki nilai-nilai multikulturalisme. Penelitian yang dilakukan Nugroho (2013) terbatas pada pengembangan bahan ajar berbasis cerita 
tradisional tanpa mengaitkannya dengan kearifan lokal setempat. Penelitian Puspitaningrum dan Suseno (2015) memang berkaitan dengan pengembangan buku pengayaaan berbasis cerita rakyat, tetapi berbeda dengan penelitian ini pada sasaran jenjang pendidikan dan produk yang dihasilkan.

Aktivitas kedua survei pendahuluan ini telah mendapatkan informasi tentang kebutuhan siswa dan guru, terutama yang berkaitan dengan produk yang bermuatan cerita rakyat dari Provinsi Lampung. Kebutuhan siswa meliputi buku pengayaan yang berisi cerita rakyat Lampung dan yang memuat kearifan lokal, serta memiliki keterbacaan yang tinggi. Sementara itu, guru membutuhkan buku pengayaan yang dapat mendukung KD 3.9 dan 4.9 yang berisi kearifan masyarakat Lampung dengan desain yang menarik. Setelah semua informasi terdata, peneliti melakukan pemetaan poin-poin yang dibutuhkan untuk memperkaya produk yang dihasilkan.

\subsection{Pengembangan Prototipe}

Tahap pengembangan prototipe ini terbagi menjadi tiga langkah. Pertama, menentukan cerita rakyat yang akan dikembangkan untuk mendukung gerakan literasi sekolah. Tiga cerita rakyat yang dipilih berjudul Kramat Silem, Waysebuga, dan Gadis Penenun Tapis. Ketiga cerita tersebut mewakili tiga jenis cerita rakyat yang akan diberikan kepada siswa, yaitu mitos, legenda, dan dongeng. Ketiga cerita tersebut memberikan pesan moral yang erat kaitannya dengan prinsip hidup orang Lampung. Prinsip hidup tersebut antara lain karakter untuk bergotong royong, memegang teguh adat, menghormati tamu, dan mudah beradaptasi dengan lingkungan. Kedua, memperkaya cerita rakyat dengan piil pesengiri (juluk adek, nemui nyimah, nengah nyappur, dan sakai sambayan). Hal ini bertujuan mengenalkan sedari dini perilaku tokoh yang dapat diteladani kepada para siswa. Ketiga, menentukan kompetensi dasar untuk mendukung proses pembelajaran di kelas.

\subsubsection{Desain Produk}

Pada tahap desain produk ini, ada lima langkah utama yang dilakukan. Langkah-langkah tersebut adalah sebagai berikut.

1) Mendesain konstruksi cerita rakyat yang bermuatan piil pesengiri.

2) Merancang petunjuk penggunaan buku untuk siswa dan guru agar sesuai dengan peruntukannya.

3) Melakukan modifikasi Rencana Pelaksanaan Pembelajaran (RPP) 
yang diterbitkan Kementerian

Pendidikan dan Kebudayaan.

4) Merancang kertas aktivitas siswa.

5) Menyusun kelengkapan desain produk yang sesuai dengan Peraturan Menteri Pendidikan dan Kebudayaan Nomor 8 Tahun 2016, meletakkan ilustrasi yang dibutuhkan, serta menyunting perwajahan.

Penyajian model buku pengayaan berbasis cerita rakyat Lampung terdiri atas bagian-bagian berikut.

a. Sampul

Tampilan sampul memuat: a) Judul depan buku pengayaan, Gadis Penenun Tapis; b) Bahan pengayaan-pengayaan tingkat dasar; c) Institusi pengembangan produk, yaitu Universitas Lampung; d) Peruntukan buku, yakni bagi guru dan siswa; e) Ilustrasi yang terkait dengan cerita rakyat; dan f) Nama peneliti.

\section{b. Sekapur Sirih}

Halaman ini berisi ucapan syukur kepada Tuhan pencipta alam semesta, tujuan pembuatan buku, dan keistimewaan buku. Selain itu, halaman ini berisi ucapan terima kasih ke berbagai pihak yang telah membantu dalam proses penelitian. Halaman ini juga berisi daftar isi keseluruhan bagian produk buku pengayaan berbasis cerita rakyat Lampung. c. Daftar Isi

Halaman ini berisi daftar isi keseluruhan bagian produk buku pengayaan, baik buku untuk siswa maupun buku untuk guru.

d. Salam Literasi

Halaman salam literasi memuat latar belakang lahirnya buku pengembangan hingga ke tangan pembacanya. Salam literasi ini juga memotivasi siswa untuk menanamkan kebiasaan membaca sejak dini dengan segala keuntungan yang akan dipetik di masa mendatang. Selain itu, terdapat juga kompetensi dasar yang dapat menjadi rujukan guna mendukung proses pembelajaran di kelas.

e. Pemetaan Indikator Pembelajaran (Buku Guru)

Pemetaan indikator pembelajaran ini bertujuan agar guru memeroleh gambaran secara menyeluruh dan utuh tentang semua standar kompetensi dan indikator dari tema yang dipilih.

f. Rancangan Pelaksanaan Pembelajaran (Buku Guru)

Halaman ini berisi refrensi bagi guru agar pembelajaran di kelas dilaksanakan secara sistematis dan terencana dan tujuan dari pembelajaran tercapai. RPP yang digunakan adalah RPP yang telah diterbitkan oleh 
Kemendikbud tahun 2016 yang telah dimodifikasi peneliti sesuai dengan kebutuhan siswa dan guru.

g. Petunjuk Guru (Buku Guru)

Halaman ini berisi petunjuk bagi guru untuk melaksanakan tujuan pengembangan buku pengayaan, yakni untuk kebutuhan literasi, penguatan pendidikan karakter, dan pendukung proses pembelajaran di kelas.

\section{h. Petunjuk Siswa (Buku Siswa)}

Halaman ini berisi petunjuk bagi siswa untuk membaca buku pengayaan yang terdiri atas tiga cerita, yaitu mitos Kramat Silem, legenda Waysebuga, dan dongeng Gadis Penenun Tapis.

i. Peta Konsep

Berisi alur isi buku cerita sehingga pembaca dapat mengetahui isi buku pengayaan secara keseluruhan.

j. Komposisi Produk

Bagian ini berisi tiga cerita tradisional, yaitu dari mitos Kramat Silem, legenda Waysebuga, dan dongeng Gadis Penenun Tapis. Ilustrasi yang menarik diharapkan dapat meningkatkan minat siswa untuk membaca buku ini hingga tuntas.

k. Lembar Aktivitas (Buku Siswa)

Halaman ini berisi latihan yang menyajikan tiga pilihan jawaban. Kategori A, B, dan C akan menentukan sejauh mana karakter yang dimiliki oleh siswa usai membaca buku ini.

1. Daftar Pustaka

Halaman ini berisi sumber rujukan atau referensi dalam proses pembuatan buku pengayaan.

Setelah melalui proses pengembangan tersebut, buku pengayaan memiliki karakteristik yang khas, berbeda dengan buku pengayaan lainnya. Karakteritik tersebut adalah sebagai berikut.

1) Model buku pengayaan ini sangat mendukung program literasi yang ada di sekolah.

Kebutuhan guru dan siswa terhadap buku pengayaan berisi cerita rakyat Lampung terpenuhi dari tiga jenis cerita yang disajikan, yaitu mitos, legenda, dan dongeng. Agar pelaksanaan literasi dapat berjalan maksimal, buku ini memiliki petunjuk bagi guru dan siswa. Petunjuk bagi guru berisi langkah-langkah pelaksanaan literasi di dalam kelas, sedangkan petunjuk bagi siswa berisi cara menggunakan buku secara efektif.

2) Model buku pengayaan ini sangat mendukung penguatan pendidikan karakter siswa. 
Salah satu cara untuk menimbulkan dan menguatkan pendidikan karakter siswa buku ini berisi pedoman hidup masyarakat Lampung yang dikenal sebagai piil pesengiri. Nilai-nilai tersebut tertanam dalam tiga jenis cerita, yaitu mitos Kramat Silem, legenda Waysebuga, serta dongeng Gadis Penenun Tapis. Sisipan piil pesengiri dalam cerita tersebut akan mengenalkan karakter yang lebih baik kepada siswa. Melalui legenda Waysebuga, siswa akan belajar hidup bertanggung jawab melalui bejuluk beadek dan belajar bermusyawarah mufakat melalui nemui nyimah. Melalui mitos Kramat Silem, siswa akan lebih dapat mengenal budaya gotong royong yang telah melekat sejak zaman nenek moyang. Semangat kerja sama ini merupakan cerminan sakai sambayan. Melalui dongeng Gadis Penenun Tapis, siswa akan belajar lebih peduli, setia kawan, dan hormat pada orang lain. Sikap ini merupakan ceminan dari nengah nyappur.

3) Model buku pengayaan ini mendukung pembelajaran dengan tema Daerah Tempat Tinggalku. Pengembangan buku berjudul Gadis Penenun Tapis untuk menunjang pembelajaran dengan tema Daerah Tempat Tinggalku. Oleh karena itu, buku ini meliputi buku siswa dan buku guru. Untuk produk yang ditujukan kepada guru, dilengkapi dengan pemetaan indikator pembelajaran dan RPP . Dengan demikian, buku ini dapat digunakan oleh guru kelas 4 tingkat SD. Khusus untuk siswa, terdapat lembar aktivitas yang bertujuan mengetahui nilai-nilai kearifan lokal apa saja yang diperoleh siswa.

Setelah mendesain produk, tahap selanjutnya adalah melakukan validasi desain dengan melibatkan tiga orang pakar.

\subsubsection{Validasi Produk}

Pada tahap ini, produk dinilai kelayakannya oleh para pakar. Tiga orang pakar memberikan penilaian berdasarkan kuesioner yang telah disiapkan. Kuesioner berisi empat poin penilaian, yaitu kelayakan isi, kebahasaan, penyajian materi, dan kegrafikaan.

Pakar materi memberikan beberapa masukan, seperti pemerkayaan referensi dan perbaikan ejaan yang salah ketik. Pakar media memberikan beberapa catatan, yaitu mengubah logo universitas yang baru, menambahkan ilustasi pada judul cerita, memperbaiki ukuran footer, 
dan menggunakan warna-warna yang lebih cerah. Praktisi menyarankan agar menambahkan batas skor siswa dan pemetaan indikator.

\subsection{Revisi Produk}

Beberapa perbaikan dari pakar materi, media, dan praktisi diimplementasi-kan dalam produk. Hasil revisi kemudian dinilai oleh pakar dalam tabel penskoran yang telah tersedia. Penilaian dua pakar dan satu praktisi menyatakan bahwa bahan ajar sangat layak untuk digunakan bagis siswa kelas 4 tingkat sekolah dasar setelah perbaikan.

Dengan demikian, menurut pakar materi, media, dan praktisi, buku pengayaan ini sudah sangat layak untuk digunakan karena mencapai skor ratarata 86 persen. Tingkat kelayakan buku pengayaan memenuhi standar dari segi kelayakan isi, kebahasaan, sajian, dan kegrafisan.

\section{Penutup}

Dari beberapa rangkaian tahapan analisis dan pembahasan pada pengembangan buku pengayaan berbasis cerita rakyat Lampung diperoleh simpulan sebagai berikut.

Pengembangan penelitian berpijak pada kebutuhan siswa dan guru terhadap bahan bacaan berisi cerita rakyat
Lampung. Buku tersebut tidak hanya memiliki tingkat keterbacaan tinggi, tetapi juga memiliki ilustrasi yang menarik.

\section{Pengembangan}

produk

mengguna-kan tahapan pengembangan Borg $n$ Gaal. Pengembangan menghasilkan dua model buku pengayaaan yang terdiri atas buku guru dan buku siswa. Buku Model pengembangan terdiri atas tiga jenis cerita rakyat, yaitu mitos Kramat Silem, legenda Waysebuga, dan dongeng Gadis Penenun Tapis. Buku-buku tersebut sarat akan nilai piil pesenggiri yang dimiliki masyarakat Lampung.

Hasil pengembangan model buku pengayaan telah dinilai layak digunakan oleh siswa kelas 4 SD. Rata-rata total penilaian dari dua pakar dan satu praktisi yaitu 88 persen.

\section{Daftar Pustaka}

Hadikusuma, H. (1989). Masyarakat dan Adat-Budaya Lampung. Bandung: CV Mandar Maju.

Herpratiwi. (2016, November). Pendidikan Berbasis Budaya Lokal di Era Teknologi. Lampung Post.

Mehta, V. (2013). Literature-Oriented Multicultural Education in India. Multicultural Education. 
Nugroho, A. (2013). Pengembangan Bahan Ajar Sastra Berbasis Cerita Rakyat Musi Rawas Kelas V SD Negeri Karyadadi Kabupaten Musi Rawas. Universitas Bengkulu.

PPSDK. (2018). Pedoman Kajian Bahan Kebijakan Teknis. Jakarta: Badan Pengembangan dan Pembinaan Bahasa.

Puspita, N. K. dan S. (2015). Pengembangan Buku Pengayaan Menyusun Teks Cerita Pendek Berbasis Kearifan Lokal bagi Siswa.
Lingua, 11 (Universitas Negeri Semarang).

Rahmanto, B. (1988). Metode Pengajaran Sastra. Yogyakarta: Kanisius.

Riduwan \& Sunarto. (2009). Pengantar Statistika. Bandung: Alfabeta.

Sarumpaet, R. K. T. (2009). Pedoman Penelitian Sastra Anak. Jakarta: Pustaka Obor.

Sugiyono. (2013). Metode Penelitian Pendidikan. Bandung: Alfabeta. 